\title{
Morphology Test Code
}

National Cancer Institute

\section{Source}

National Cancer Institute. Morphology Test Code. NCI Thesaurus. Code C117606.

A character or string that represents the short code name of the morphology assessment. 